\title{
Participation of the Ethiopian Police Contingent in the United Nations Peace Operations: Focus on the Role and Challenges
}

\author{
Tensae Gebrekrstos Gebreegziabher \\ Ethiopian Police University, P.O. Box, 1503, Sendafa-Ethiopia
}

\begin{abstract}
This research article delved the role and challenges of the Ethiopian police contingent in the United Nations peace operations. To this end, the author used socio-legal research method. Both primary and secondary data collections tools were employed. Key informant interview based on the mission experience were used to collect primary data. Secondary data critically reviewed relevant normative frameworks, standards, official reports, websites and other materials. The finding indicated that the Ethiopian police contingents are performing policing roles including crime prevention; strengthen administration and capacity of local police, restructure and reform of the host states police. Nevertheless, Ethiopia's participation remains very low and even nonexistent in most of the peace operations. The finding also indicated that lack of normative and institutional arrangements are among the major challenges of the police contingent. This in particular includes lack of clear selection guideline of the police for mission, pre-deployment training deficiencies to the police candidates on mission language, driving skill and mission area courses and lack of well-established training centers. This in turn stalled the Ethiopian police not to significantly respond to the call for UNPOL peace operations. Hence, Ethiopia's normative frameworks and institutional arrangements should be in line with the UNPOL legal and policy frameworks. In this regard, lessons ought to be drawn from Rwanda, Ghana and Nigeria.
\end{abstract}

Keywords: United Nations Police (UNPOL), Peace Operation, Role, Challenges

DOI: $10.7176 / \mathrm{JAAS} / 76-02$

Publication date:October $31^{\text {st }} 2021$

\section{INTRODUCTION}

The United Nations (UN) Charter is the grand norm for the conduct of all peace operations. During the Cold War, traditional UN peacekeeping missions largely consisted of unarmed or lightly armed troops and their primary role was limited to maintaining cease-fires and peace agreements. With the end of the Cold War, however, the nature of conflicts in many parts of the world changed from interstate to intrastate conflicts. Soon, the nature and role of peace operations also changed (United Nations Police history, 2019).

Though the establishment of United Nations Police (UNPOL) service suggested in 1948, police component as a part of the UN military operation was for the first time deployed in the UNs Operation in Congo (ONUC) in 1960. Police officers from Nigeria, Ghana and some members of the Ethiopian Police along with the military component were deployed to assist to the Congolese government to maintain law and order. From 1962-1963, the UN Temporary Executive Authority for the West New Guinea became the first mission where the UN hired police experts for law enforcement duties in a peace operation (United Nations Department of Peacekeeping Operation (UNDPKO), 2011).

The number and size of UN peacekeeping deployments grew exponentially as did the role and mandates of UN Police. The growing importance of the police contingent (also known as police component) in UN missions have been amply demonstrated in the East Timor and Kosovo, where UNPOL has exhibited its capabilities in maintaining civil order in a country divided along ethnic, religious and cultural lines. During the Cold War era, policing efforts in peacekeeping operations concentrated on the support, monitoring, advising and training of local police while the post-Cold War era becomes increasingly complex including stability and capacitybuilding tasks. Recently, the UN Police has become an important part of UN peace operation (UNDPKO, 2011).

Recently, the United Nations Police has become an increasingly visible and important part of UN peace operation. Not only their number but also their role has evolved over time. Particularly, African countries such as Senegal, Rwanda, Nigeria and Ghana have shown an increasing willingness to contribute police to UN peace operations. Despite the fact that Ethiopia has become one of the top troops contributing countries in the world, its role in policing component remains low and nonexistent in several UNPOL peace operations. Ethiopia sends its first police contingent to the then UNMIS in April 2008. Since then, only a few police officers have been deployed to the UNMISS; UNAMID and UNISFA (UNDPKO, 2011; United Nations Police Contributors, 2021). Therefore, this article critically examined the role and challenges of the Ethiopian police contingent in the UN peace operations.

\section{LITERATURE REVIEW}

\subsection{Police peace operation: Explained}

The term 'peace operation' is a vague term that is not consistently defined (Findlay, 2002). Peace operation is 
defined as an actual field activity to prevent or control violent conflicts or to lessen the risk of their return. These include conflict prevention, efforts to establish sustainable peace with the agreement of parities to the conflict, coercive measures to stop armed conflict, and rebuild states after conflict. The term "peace operation" and "peace keeping" can be used interchangeably. Because, both are broad, generic and often imprecise terms to describe the various activities that the UN and other organizations undertake to promote, maintain, enforce or enhance the possibilities for peace. Though such enterprises were not the minds of those who draft the UN Charter, peace operations however evolved into one of the most remarkable achievements of the UN. The concept peacekeeping has long been favored by the UN to describe military operations that are conducted with the consent of various warring parties. Nowadays, however, peacekeeping operations are defined as actions undertaken to enhance global peace and security by supporting member states in conflict and post conflict situations (United Nations Peacekeeping Operations, Principles and Guidelines, 2008).

Peace operation is the umbrella term that applies to all UN missions including peacekeeping, peace building, peacemaking, conflict prevention and peace enforcement. It is a multidimensional operation that includes a mix of police, military and civilian components working together to lay the foundations of sustainable peace. The UN peace operations regardless of the term used to describe peace operations and the essence of such operations is that they have an international character aimed to maintain international peace and security. Though none of the classification schemes are commonly agreed, there are six categories of peace operations to restore peace and security. That is, preventive diplomacy, peacemaking, peacekeeping, peace enforcement, peace building and sanctions. These concepts reflect the growing scope and complexity of UN peace operations and useful insight into how the world can more fully embrace and achieve its objectives laid down in the UN Charter (United Nations Peacekeeping Operations, Principles and Guidelines, 2008), which is shown on below picture.

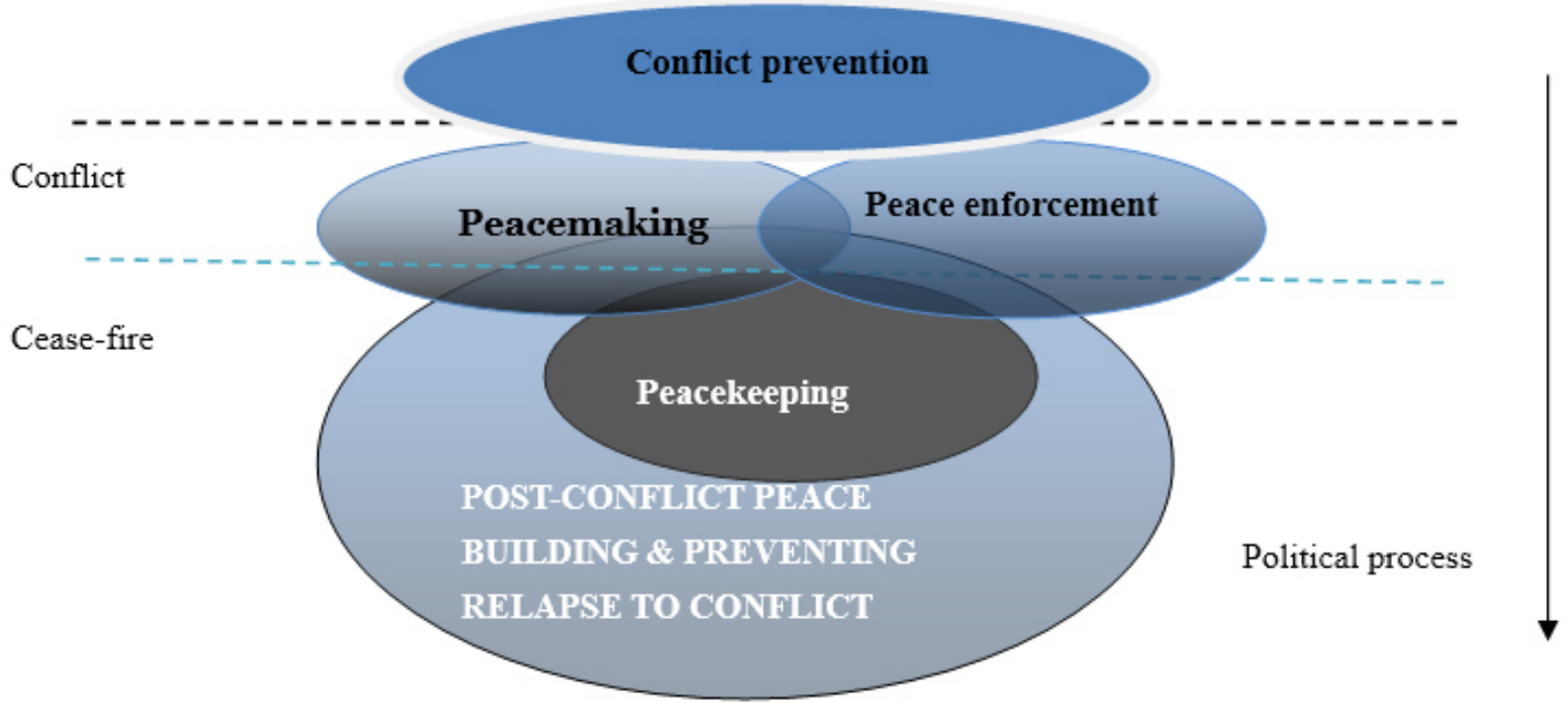

Figure 1- Linkages and gray areas of UN peace operations

The boundaries between conflict prevention, peacemaking, peacekeeping, peace building and peace enforcement have become increasingly blurred. Conflict prevention, peacemaking, peacekeeping and peace enforcement rarely occurs in a linear or sequential way. Indeed, experience has shown that they should be seen as mutually reinforcing (United Nations Peacekeeping Operations, Principles and Guidelines, 2008).

\subsection{Legal and institutional frameworks vis-a-avis UNPOL peace operations}

Ethiopia is expected at all times abide by international norms and promote peaceful instruments of regional and international diplomacy and take active roles in global security (FDRE Foreign Affairs and National Security Policy, 2002). However, there is no constitutional provision that specifically deals with the decision-making process for the deployment of Ethiopian police component to peace operations. Further, there is no specific and comprehensive legislation to effectively respond to international call to peace operations.

Implementation of laws adopted by the House of Peoples' Representatives including supervising the overall implementation of the country's foreign policy is one of the principal functions of the Ethiopian Prime Mister. This includes decisions on the deployment of the country's security forces because he is the Head of Government and the Commander in Chief of the Armed Forces (FDRE Constitution, 1995, Art.74). The parliament does not have an active role in decisions regarding deployment of police force to peace operations missions. Ethiopia's recent experiences in peacekeeping also show that the Prime Minister is the leading decision-maker on this issue. The Prime Minster and the ministries involved at a strategic decision-making level and the specific tasks related to deployment and related activities are left to the Federal Police Commission 
(FPC). The political decision-making process of deployment of both military and police component to peace operation is alike in Ethiopia. Unlike the latter, the former is well institutionalized in responding to international call for peace missions (Ethiopian International Peace Keeping Training Centre, 2019).

The FDRE has a police force organized at Federal and Regional levels. The Federal and State have their own police force. As a result, the Ethiopian police system consists of a Federal Police, nine Regional Police and the Police Forces of Addis Ababa and Dire Dawa City Administrations. The FPC is headed by the Ministry of Peace. Article 6 of the Federal Police Commission Establishment Proclamation defines the objective of the Commission as maintaining the peace and security of the public by complying with and enforcing the constitution and other laws of the country. The Proclamation describes the duties and powers of the police commission. Foreign policies, including international agreements or conventions are Federal matters and here international peace operations regarding police component are under the FPC (FDRE Constitution, 1995, Art.55). Sub article 34 of Article 6 of the Federal Police Commission establishment proclamation in this regard reads as "The commission shall have the powers and duties to prepare a peacekeeping police force which can properly accomplish international peace keeping call of the country." The FPC is the principal organ for the deployment of police force to international peace mission and it has coordinating duties at the national level including training, professional and technical advice and support for regional police force. The proclamation doesn't have any further indication to explain this provision for the most part on the issues of selection and pre-deployment training. There are however few provisions relating to the obligation of the Commission to establish a training center to train and equip police officers to help them perform their policing tasks effectively. This includes the obligation to provide training police officers to drive motor vehicles and issue driving licenses.

The Federal Police Council of Ministers Regulation No.268/2012 is also silent on the deployment of police force to international peace missions. Though constrained by many defects and not yet fully functional, the Peacekeeping Directive enacted in 2013 is the only subsidiary legislation to regulate the police in peace operations. The directive has three main parts. Part one deals with the general provision mainly on scope, basic principles and objectives regarding peacekeeping operations (Directive no.7/2013, arts. 1-4); part two of the directive deals with some issues regarding to selection criteria and pre-deployment training and duties of police members in peacekeeping operations (Directive no.7/2013, arts.1-4, 6-13 and 14-17); the third part deals with post deployment issues (Arts. 1-4, Art. 18-20).

Whenever a police officer deployed to any international missions, it is part of his/her policing duties. The Federal Police Officers Administration Council of Ministers Regulation No.268/2012, Article 8 (2) strengthens this idea, says "A police officer shall have the obligation to accept any assignment of duty, including overseas assignment where necessary." On the other hand, article 13 (3) of the directive puts an obligation to police officer who is deployed to peace operations to pay $5 \%$ of his/her allowance to the Federal Police Peacekeeping office. Failure to pay for consecutive three months results the officer to return from the mission before completing the mission and forced to pay it from his monthly salary. Article 13 (4) of the same directive reinforces this obligation. The UN pays the police officer as an allowance for daily consumption. Their monthly salary is to be paid by their national governments upon return from mission (Sule, 2019).

Researches relating to the role and challenges of police in international peace operations have so far received very little attention. Even the scanty research conducted in this regard are not comprehensive and do not reflect the reality in Ethiopia. Therefore, this research critically examined the roles and challenges of the Ethiopian police contingent in the UN peace operations.

\section{RESEARCH METHODS}

Socio-legal research design was used to conduct this research. In undertaking non-doctrinal research, the researcher takes either some aspects of law or the people and institutions supposedly regulated by law as the focus of his study. A socio-legal research method is important to scrutinize both the gaps in the law and practice. In this research method, primary and secondary data collection tools can be utilized (Vibhute \& Aynale, 2009). Both primary and secondary sources were used to gather pertinent data for this particular research. Key informant interview based on the mission experience were used to collect primary data. The four interviewees asked their mission experience, challenges they face in the field and challenges that hinder the police force from participating in the UNPOL peace operations. Besides, both domestic and international normative frameworks were consulted. Whereas the secondary sources include books, journal articles, reliable web sites and other materials on the subject matter. Pertinent documents were consulted and thematic analysis was also used. Documents are helpful and can provide special details to corroborate information from other sources and also important to make inferences. In this study, the validity of the data collected were assured using one of the types of triangulation; the triangulation of sources. The triangulation of sources involves comparing the information gathered through different data collection instruments used in the particular research such as interviews, observations and document analysis (Ritchie \& Lewis 2003). 


\section{RESULTS AND DISCUSSIONS}

\subsection{The Role and Challenges of Ethiopian Police Contingent in the UNPOL Peace Operations}

In the past few years, many countries have shown an increasing willingness to contribute police for UN peace missions, particularly, since 2003 where UNPOL contributions from African nations have grown dramatically both in absolute numbers and as a percentage of total UNPOL deployed (UN Peacekeeping Operations, Principles and Guidelines, 2008). While some of the African countries such as Nigeria, Ghana and Rwanda police have been significantly increasing their police role both at the regional and global level, Ethiopia did not participate at all before 2008. Only, the military component was considered to be a peacekeeper. One can argue that Ethiopia does not yet take sufficient advantage of all the opportunities given by the UN to deploy more police to peace operations (UN Peacekeeping Operations, Principles and Guidelines, 2008). In 1960s, police officers from Congo, Ghana and Nigeria were deployed to help restore the rule of law in the country. Members of the Ethiopian police were also sent to the Congo peace mission under the first Tekil Brigade with the aim of performing policing duties (Haile, 2006).

The Ethiopian government believes that its internal security is dependent on the security of its neighbors, the sub-region, the region, and the world at large. Through time it has become increasingly obvious that it's not only the stability of neighboring states, but also regional security disturbances, directly or indirectly, that affect the process of development in the country (FDRE Ministry of Foreign Affairs, 2019). As part of this commitment Ethiopia in 2008, for the first time in its history sends the first police contingent to Sudan UNMIS police. Since then, the country has deployed few police officers to UNMIS/UNMISSES, UNAMID and UN Interim Security Force for Abyei (UNISFA) and recently to Haiti. Ethiopia sends its first batch police officers to UNMIS mainly to reform and restructure the Sudanese Police Service, develop police training and evaluation programs (UN Police Contributors, 2019).

From 1990s forwards, calls for the engagement of UN Police in support of the local police have increased and its mandates have become complex and multidimensional moving beyond traditional monitoring. Advisory,mentoring and training functions have become core duties to reform, restructure and rebuild the host country police agencies with the ultimate aim of capacity enhancement. Thus, the Ethiopian police like other nations police have been playing these non-executive functions in the UNMIS (United Nations Mission in the Sudan, 2011).

As stated earlier, the Ethiopian police officers have been working closely with their Sudanese counterparts. The overall, commitment of Ethiopian peace operation forces deserves praise (Dalil, 2016). Specifically, their participation in training community policing, traffic management, leadership and livestock patrol; policing tasks mainly on crime prevention and investigations; strengthen administration and planning capacity of police, communication, reporting, control and restructure, reform and develop the capacity of South Sudan Police Service to ensure delivery of a professional and accountable police service to the needs of South Sudanese People(United Nations Mission in the Sudan,2019).

Involvements in peace operation have human, material and financial losses for the country that deploy peace force. But if it is carefully planned, peace operation has political, economic and societal gains to Ethiopia. Politically, Ethiopia has been using the mechanism of peacekeeping to translate her inspirational quest for African leadership into reality. Its contributions to UN peace operation have contributed to boosting the country's police diplomatic status within the global and regional system. Arising from peace operation thus the international community particularly African countries have come to appreciate the centrality of Ethiopian to African affairs. Indeed, the roles of Ethiopian police peace officers have been commended by host societies and mandating authority (Dalil, 2016).

Although individual officers can benefit significantly through receipt of UN allowances, economic rationale is not a significant influence on the Ethiopian government policy. But the military component relies on reimbursements to fund training and procurement. Further, the peace operation contribution opens new opportunities for police support from major donor countries such US. In the case of Formed Police Unit (FPU), it is common also to have reimbursements but as Ethiopia's police role is limited to Individual Police Officers (IPOs) there is no repay. To these police officers who participated in peace missions, there is a significant economic benefit. The police officers who have served in UNMIS/UNMISS UNAMID and UNISFA were successful in this regard. But looking UN peace operation from an economic perspective is one of the usual problems of the Ethiopian police force. The challenges of peace operation at ground are not considered. Usually, the Commission selects officers who are around retirement age to benefit them economically. It is good to help the individuals nonetheless the competence of officers who are going to represent their country should also be considered (Personal communication, 14 April 2021).

Participation in the UNPOL peace operation can bring important theoretical and practical experience for the Ethiopian police officers and the police institutions. Each returning police can share valuable experiences and insights that may benefit and help the modernization of the police system in the country (Personal communication, 14 April 2021). 
According to the Federal Police Commission Peace Keeping Division, Statistical Data of Police Peacekeepers for the period 2014-2015, the first police force deployed to UNMIS were only 15 police officers. The total number of police officers selected for UNMIS police tasks were 153 members of Federal Police Personnel from different departments and only 15 of them have passed the exam for the mission. Since then, the number of police officer selected for the entrance exam has been relatively large and the numbers of police who pass have been very small. Even in the second and third batch only, 8 police from 116 and 20 from 139 police officers respectively have passed the exam. To date, the situation is almost similar. The author's interview with experienced police commanders who participated in the previous UNMIS, UNMISS and UNAMID police indicated that the reason why most police officers fail to go to the call for peace operation mission are associated with selection and pre-deployment trainings (Dalil,2016). All of the interviewees stated that some officers fail at the first phase (written exam); others at the second phase (driving skill) while others at a final phase (interview). Even today, some police officers fail to extend their stay in mission. One of the reasons is inability to pass further driving test in the mission area. These are among the common challenges of the Ethiopian police officers (Personal communication, 22 April 2021).

After consulting with Member States, the UN has developed basic pre-deployment selection standards for Member States to be used in identifying and selecting qualified police personnel for successful tasks in peace operations. These standards serve as minimum preparation requirements in the selection and testing process of personnel for peace operation assignments. As stated before, UN Police officers are contributed by a large number of nations with differing policing systems, training and specializations. Thus, to support the individual police officer to adjust to the challenges of new and different living and working conditions in a peacekeeping field, these are part of the UN's commitment to ensure that all peace officers are properly prepared for peace operations (UNDPKO, Selection Standards and Training Guidelines for United Nations Civilian Police, 1997). In this regard, the UN Charter under Art.101 (3) states:

the paramount consideration in the employment of the staff and in the determination of the conditions of service shall be the necessity of securing the highest standards of efficiency, competence, and integrity. Due regard shall be paid to the importance of recruiting [selecting] the staff on as wide as a geographical basis as possible.

As stated in the UNDPKO Selection Standards and Training Guidelines (1997):

a police officer must be a sworn member of the police force he/she is representing, and a citizen of their Member State; a police officer must be physically, psychologically and medically fit; immunizations must be obtained prior to deployment; must have a minimum of 5 year experience in an active police capacity; proficient in their own official language and in the official language of the mission; possess a valid driver's license, be able to operate a $4 \times 4$ vehicle in any driving conditions, and pass the required driving test before deployment; excellent personal and professional integrity are among the minimum pre-deployment selection standards.

The UNDPKO has also developed Standard Operating Procedure called the Assessment of IPOs for Service in UN Peacekeeping Operations and Special Political Missions (AMS). AMS Police officers looking to deploy to a UN mission must be adaptable and comfortable in different social and cultural settings; have the skill to accomplish the duties of the mission they are selected; be knowledgeable about the overall mission environment and the parties to the respective conflict are among the added criteria (UNDPKO, 2012). Broadly, these skill sets apply to any police missions. Hence, Ethiopian police like other countries police are expected to fulfill these requirements before any deployment to any international peacekeeping missions.

Once a given national police service has recruited and selected potential candidates, Member-States utilize Selection Assistance Teams (SATs) to conduct assessments based on the skills and qualifications of selected candidates. SAT evaluates the candidate's language skills; report writing; comprehension; driving and shooting skills. Completing these evaluations, the SAT team measures the suitability of the candidacy pool for UN Police deployment. Then a final report is submitted to the Chief of Police of the national police service with a list of qualified police officers attached. There is also Standard Operating Procedure Assessment of Individual Police Officers for Service in United Nations Peacekeeping Operations and Special Political Missions (UNDPKO, 2017). However, assessment of Ethiopian police is not in line with this norm. Because, before 2013, there were no separate institutions that regulate the deployment of neither police force nor specific legal procedure for the proper screening of police officers. Thus, the selection criteria is not in line to the UN standard rather periodically changeable criteria; the existing directive on international peacekeeping is not sufficient to overcome the challenges facing by a police organization and even it was not enacted by consulting relevant stakeholders and the pre-evaluation preparation is even not practicable (UNDPKO,2017).

The Nigerian Police Force unlike the Ethiopian police is well institutionalized with respect to international peace operations. The Peacekeeping Office of Nigerian Police established in 2005 with clear vision and it is largely focused on research, training and deployment to peace operations. The principal mission of the office is to equip police officers to meet the complex nature of peace operations through professional training. To 
accomplish this vision and mission Peacekeeping Operations and Training Centre has established. This center has four Operational Support Units namely the Logistics, Training Unit with its Field Training Subunit, the Technical Unit and Human Resources Unit where each has their own specific tasks regarding any peace operation assignments abroad (Ford,2006).

Problem of mission language is among the usual challenges that the Ethiopian police officers have been facing since 2008. Interacting with individuals in a different language is vital to facilitate capacity-building in a post-conflict society. To communicate with fellow contingents and report daily activities, learning and knowing basic phrases and greetings in mission-specific areas such Arabic for missions in Sudan is paramount to get confidence of the people of that area (Haile, 2006). Currently, the peacekeeping division which is the sole and the responsible organ in the country does not provide language training courses for its police officers as part of pre-deployment training nor have training center established for this purpose. In fact, the Ethiopian Police University (EPU) has established "Peacekeeping Support Center" in 2018. However, it is not fully functional and its mandate is not clear. One of the major problems in the mission is a language problem. Though there are some efforts to train the police officers, the Ethiopian peacekeepers serving in international missions face similar challenges (Dalil, 2016). In 2017, few police officers from Haiti have returned to their country due to language problem. The author's interviewees stated that police officers from other African countries such as Kenya, Nigeria, Ghana, and Rwanda are very fluent to communicate in mission language. Even to win leadership role such as a team leader and above, the UN demands talented individuals who are able to communicate easily.

Driving skill is another challenge for many Ethiopian police officers. It is one of the basic requirements to take part in the UN and AU Police peace operations. Thus, police officers are limited in their ability to apply for any peace operations because they do not know how to drive. Particularly, female police officers have been challenged by this problem. It is one reason for having almost none Ethiopian female peacekeepers in UNMISS, UNAMID and UNISFA. During the first batch in UNMIS, lack of driving skill was a reason for the returning of some Ethiopian police officers before accomplishing the expected role (Personal communication, 22 May 2021). As stated in article 6 (36) of FPC Proclamation No.720/2011, one of the duties of the commission is to "provide training for police officers to drive motor vehicles and issue driving licenses to them upon obtaining an accreditation certificate from the Transport Authority in accordance with Proclamation No. 600/2008". The latter Proclamation is to mean the Driver's Qualification Certification License Proclamation No. 600/2008. But there is no such regular training carried out by the Commission for the purpose of international peace operations and suggested that it is a must to train police candidates before any deployment is commenced. Though not fully functional, at the EPU compound, there is a language laboratory established some years before (EPU organizational structure, 2018). Hence, this is a good opportunity for the peacekeeping center to train its police force for international missions.

Lack of proper selection criteria for police peace officer will have a direct impact on the accomplishment of assigned tasks in the mission area. Hence, proper criteria and standards should be set and implemented to send qualified personnel to peace missions (Ford,2006; Haile, 2006) If the decision is made to send someone on a peace operation and he/she is not the appropriate person for the position, the potential effectiveness and image of the Ethiopian police force, the country as a whole is hurt, both abroad and within the country. This is also true with regards to the military component (Personal communication, 23 April 2021).

As in Nigeria's, the Ghana Police Service incorporated the UN deployment evaluations for Peace operations as part of its own pre-selection process. Any Ghanaian police officer can participate in international peace operations if he/she is a rank of corporal and above, and the rank of Sergeant or above for AU missions. Men must have at least eight years of policing experience while women must have seven years. All officers must be of good character, and must wait for four years, on their return from the previous mission, to participate on another mission. This provides other members of the Ghanaian police service the opportunity to be deployed abroad. Any police member can participate in any missions if she/he has a minimum of five years in the police service; rank is not an issue in the deployment of police officers abroad, though lower ranking officials generally hold the rank of corporal or higher after five years in the service. Unlike the Ghanaian, there is no difference in the number of years of service between both sexes but must have good character. Up on returning home from a mission, a Nigerian police officer is required to stay for about 12 months before being re-deployed to another mission abroad(Ford,2006).

Article 8 of the directive puts criteria such as loyalty to the FDRE Constitution, has good ethical conduct, ability to read, write and speak English language, driving license with one year driving experience, eight years working experience in policing service, have taken basic police science, age 25-50, have the full physical fitness to participate in peace operations (Directive no.7/2013, art.8). Most of the criteria are in line with the UN Selection Standards and Training Guidelines for Civilian Police. Except few, Ghana and Nigeria have similar criteria as in Ethiopia. Here, the problem is not the criteria, but having implementing them is still the most challenging concern in Ethiopia. The commission does not follow these procedures set in the criteria than using variable procedures from time to time without any justified ground. Sometimes they put rank as a benchmark; 
sometimes age and year of experience and even some times without clear criteria. Even there are difference selection criteria among the different units of the Commission (Personal communication, 26 April 2021). As indicated above, getting qualified and competent police peace officer who can represent her/his country is very difficult without implementing such criteria.

The directive also requires a police officer, who returns after accomplishing his/her service abroad, to serve three-fold of the time he/she stayed there in the mission (Article 13 (6)). Mostly, police officer stays in a given mission to the minimal of one year and maximum one and half year through extension (Art.16 (1-2). So, she/he is duty bound to serve in the police organization for at least three and half year. In Ethiopia, as in Ghana and Nigeria there is also the possibility of returning to other mission areas (Art. 20). In Ethiopia only possible if he/she served threefold of the years he/she had in the mission; the new mission should be another mission and if there are no any competent police for the new mission and if he/she accomplished his/her tasks (Art.20 (2-3). Practically, though a police officer is competent, possibility of re-deployment to any mission is very narrow and no one has re-deployed to any mission once he/she has deployed (Directive no.7/2013, arts.13,16 and 20).

Data from the UNPOL contributors archive shows that Ethiopia has so far sent IPOs but not FPUs and other experts working in the police organizations (United Nations Police, Police Contributors, 2019). In fact, the Ethiopian Police University trained 180 police officers for FPUs for the first time in the history of the Country. Currently, they are waiting to be deployed to the mission areas probably to the Sudans (Personal communication, 27 March 2021). In 2012, UNPOL counted 14, 000 officers, among whom 7100 were IPOs tasked with support for the reform, restructuring and rebuilding of host-state police and other law enforcement agencies; implied tasks such as mentoring, advising, and training local police; law enforcement tasks depending on whether the mission is executive or non-executive mandate. For example, as it was for UNMIS, UNMISS police have nonexecutive and all Ethiopian police officers are IPOs and performing non-executive policing function. Meaning, they can't arrest or detain suspects or investigate any crime than perform capacity building tasks (UNMIS/UNMISS police, 2011). In 2014, there were eight Ethiopian IPOs under UNMISS police and they were working in the South Sudan police services (Personal communication, 22 April 2021). According to the UN Police Division, there is a never-ending demand for new police and given today's multidimensional mandates there is a constant demand for different specializations including FPUs. FPUs are increasingly needed in modern peacekeeping, but should skilled with a special training including VIP protection, special weapons, tactics and riot control and they are mandated with public order management; protection of UN personnel and facilities are among the few tasks (UNDPKO,2016).

As stated above, while the UN has designed policy and guideline to regulate overall activity of FPU, the Ethiopian legal regime including the new directive can't accommodate the requirements of training and deployment of FPU. To date, Ethiopia didn't deploy FPUs to any mission including UNMIS/UNMISS (United Nations Police, Police Contributors, 2021). There is movement to deploy FPU to international peace operations. But the author believes that in the absence of law or subsidiary legislation, skillful and experienced police officers and necessary equipment's, it is very difficult to train and deploy them as they require special training by skillful police officers. But as Rwanda does with the Kenyan, Ethiopia can train FPUs, together with these or other countries and organizations. Sharing experiences with other countries will able to enhance Ethiopian role regarding international peace operations (Personal communication, 27 April 2021).

The Ethiopian police component is limited to missions in Africa particularly to the UNMISS, UNAMID and UNISFA and only once to MINUSTAH in Haiti. As of July 2019, the numbers of Ethiopian Police force in the three missions stated above were 57 where 28 are in UNMISS, 19 in UNAMID and 10 in UNISFA. Since 2008 , the total police officers to these missions are not more than 250 officers. Specifically, the Ethiopian IPOs to UNMIS/UNMISS since 2008 is about 43 which is the largest in compare to 26 IPOs to UNAMID and 7 IPOs to UNISFA. The number of Ethiopian police officers in the UNMIS/UNMISS as in UNAMID and UNISFA in the view of many countries is very minimal. Rwanda for example is not only confined to the UNMIS/UNMISS UNAMID and UNISFA, but also deployed many police officers to UN Stabilization Mission in Haiti (MINUSTAH), UN Operation in Côte d'Ivoire (UNOCI), UN Integrated Peace Building Office in GuineaBissau (UNIOGBIS) and many more. Other African countries such as Senegal, Nigeria and Ghana are among the top police contributors to the UNPOL peace operations. Rwanda and Senegal are also called the gender champion countries (United Nations Police Contributors, 2021).

\section{CONCLUSION AND RECOMMENDATION \\ 5.1 Conclusion}

The UNPOL has become a central component of the UN's efforts to bring peace and security to conflict-torn environments. Particularly, since 1990s, calls for the engagement of UNPOL in support of the local police have increased and its mandates have become complex and multidimensional. Predominantly, countries like Bangladesh, Nepal, Nigeria, Senegal, Ghana and Rwanda have shown increasing commitment to numerous peace operations. This is largely due to strong commitment of each country government towards their police role 
in international peace operations, well-developed pre-deployment selection criteria, trainings, preparations and evaluation of police officers; diversified deployments of personnel and broadening mission areas.

Ethiopia's participation however remains very low and even nonexistent in various UNPOL peace missions. Hence, lesson ought to be drawn from Rwanda, Ghana, Nigeria and Senegal in a number of ways. Participating in UN Police peace operation, offers several benefits including reshape the Ethiopia's international profile and increase its influence in the UN. It also offers Ethiopia's police forces a range of learning opportunities. For the UN, Ethiopia can bring considerable human resources in support of UNPOL peace operation that is overstretched and having difficulty bringing missions to their full mandated strength. As part of its foreign policy, it has a strong interest in strengthening the overall role and legitimacy of the UN as a global actor and will continue to see Ethiopia police contributions to UNPOL peace operations.

\subsection{Recommendation}

Based on the foregoing facts and analysis, the author suggests the following issues:

- Ethiopia's legal regimes and institutional arrangements that govern the police component in the peace missions abroad should be in line with the UNPOL legal and policy frameworks. Since the first deployment to UNMIS, the selection criterion has not been constant and not regulated by a specific procedure. The FPC in particular should review/follow proper pre-deployment selection criteria/procedures to deploy its police force. The directive should be revised in line with the UNPOL Selection Criteria and Standards and experience should be drawn from the top UNPOL contributors.

- Ethiopia should increase and diversify its contribution to the UNPOL peace operations and beyond. Ethiopia's participation in UNPOL peace operation is very minimal and the least among the top police contributories in the world. To date, the country's participation is limited to IPOs. The country should also participate in the FPU, SPC and Special Political Missions and lesson can be taken from Ghana, Nigeria and Senegal.

- The FPC, particularly the International Peacekeeping Division along with the EPU Peacekeeping Support Center has to design and provide pre-deployment trainings to potential police candidates on mission language(s), driving skill and specific mission area courses such as humanitarian assistance, personal security, map reading, radio, communications, vulnerable groups, human rights and gender issue.

- Lack of giving due regard to international mission experience is one of the Federal Police Commission's problems. Applying police officers newly developed skill sets are useful for a country like Ethiopia where the policing profession is young and underdeveloped. Returned police officers can improve the structure of Ethiopian police institutions through their field experience. To this end, upon return from missions, police officers should consider undergoing meetings with upper management to examine ways the lessons learned from missions can be applied to their police institutions. Follow-up discussions with colleagues and senior leadership may demystify this common myth.

- The FPC as a sole responsible in sending police officers to the international police peace operations should give a chance to the regional police in the decision to send police component to the international peace operations. This narrows the bias in proposing, selecting and deploying of police component to the peace operations.

\section{REFERENCES}

Dalil D., (2016), Ethiopia Contribution to Global and African Peacekeeping Operation $<$ p.1-2 https://ippjournal.wordpress.com/2016/04/07/ethiopias-contribution...>accessed 19 March 2021

Ethiopian Federal Police Commission Peacekeeping Directive no.7/2013, Art.1-4

FDRE Foreign Affairs and National Security Policy (2002).p.88

Findlay T., The Use of force in UN Peace Operations, Oxford University Press, Oxford, New York, 2002 (first published in 2002), p. 3-7,

Ford H., (2006), Evaluating the Operational Effectiveness of West African Female Police Officers'Participation in Peace Support Operations: The Case of Ghana and Nigeria, p.2526,http://issat.dcaf.ch/eng/content/download/31928/448668/file/KAIPTC\%20Paper\%20no_23.pdf, Accesssed 18 March 2021.

Haile Araya,(2006). East African Crisis Response: Shaping Ethiopian Peace Force for Better Participation in Future Peace Operations.

Nigerian Police Forces $<$ https://www.npf.gov.ng/departments/operations.php\#>accessed 18 April 2021.

Ritchie, J. \& Lewis, J. (2003). Generalizing from qualitative research. In Ritchie, J and Lewis, J. (Eds.),Qualitative Research Practice; A guide for social science students and researchers. Sage.

Sule M., Nigeria's Participation in Peacekeeping Operations < $<$ ttps://cdn.peaceopstraining.org/theses/sule.pdf> accessed 20 April 2021.

The Constitution of Federal Democratic Republic of Ethiopia (the FDRE Constitution), Proc.no. 1/1995, Addis 
Ababa, Art.74

The United Nations Charter, Chapter XV, Art.101 (3), San Francisco, 1945

UNDPKO (2012), Standard Operating Procedure Assessment of Individual Police Officers for Service in United Nations Peacekeeping Operations and Special Political Missions, p.3-14

UNDPKO (2016), Department of Field Support, Formed Police Units (FPU) in United Nations Peacekeeping Operations

UNDPKO (2017), Standard Operating Procedure For Assessment of Operational Capability of Formed Police Units For Service in United Nations Peacekeeping Operations and Special Political Missions

UNDPKO, Selection Standards and Training Guidelines for United Nations Civilian Police (UNCIVPOL), New York, 1997

United Nations Department of Peacekeeping Operation (UNDPKO),"Sustainable Peace through Justice and Security", UNPOLICE Magazine, P.7, (6th edition, January 2011).

United Nations Mission in the Sudan (2011). Peacekeeping $<$ http://www.un.org/en/peacekeeping/missions/past/unmis/>accessed 15 April 2021.

United Nations Mission in the Sudan (UNMIS), UNMIS Mandate $<$ https://peacekeeping.un.org/en/mission/past/unmis/mandate.shtml>accessed 19 April 2021 United Nations Peacekeeping Operations, Principles and Guidelines, 2008, New York, p.17-18

United Nations Police, Our history <https://police.un.org/en/our-history>accessed 2 May 2021

United Nations Police, Police Contributors <https://police.un.org/en/police-contributors> accessed 16 April 2021.

United Nations Police, Police Contributors, https://police.un.org/en/police-contributors, Accessed 18 April 2021

UNMIS, United Nations Mission in the Sudan (2011) <http://www.un.org/en/peacekeeping/ missions/past/unmis/>accessed 13 April 2021.

Vibhute \& Aynale (2009), Legal Research Methods, Justice and Legal System Research Institute. 